\title{
Tertiary hospital standards in Nigeria: A review of current status
}

\author{
Nura H. Alkali, ${ }^{1}$ Mohammed R. Bello \\ ${ }^{1}$ Department of Medicine, Abubakar Tafawa Balewa University Teaching Hospital Bauchi, Bauchi State; \\ ${ }^{2}$ Department of Anesthesia, Federal Medical Center Yola, Adamawa State, Nigeria
}

\begin{abstract}
Nigeria's tertiary hospitals have faced public criticisms over substandard services and poor infrastructure reported in the mass media during early to mid-2019. Peer-reviewed studies in the medical literature have painted similar pictures of poor healthcare quality at most of the nation's public hospitals. For instance, studies have revealed tertiary hospitals lacking vital equipment needed for emergency care of acute asthma and obstetric hemorrhage, while hospital administrators complain of insufficient personnel made worse by inadequate electricity from the national grid, poor government funding and bureaucratic bottlenecks undermining staff recruitment and training. This grim situation is at total variance with global best practices for tertiary healthcare adopted by many countries. Matters may yet get worse with Nigeria now in the midst of a coronavirus epidemic and its potential to overburden weak healthcare systems unless urgent efforts are made to improve healthcare quality. A practical and effective way to improve healthcare quality is via strict enforcement of minimum healthcare standards in line with global best practices and the regulatory provisions of the nascent National Tertiary Health Institutions Standards Committee established by the National Health Act 2014.
\end{abstract}

Correspondence: Nura H. Alkali, Department of Medicine, Abubakar Tafawa Balewa University Teaching Hospital, PMB 0117 Bauchi, Bauchi State, Nigeria.

Tel.: +2347064276660

E-mail: nalkali@yahoo.com

Key words: COVID-19; Hospital standards; National Healthcare Act; Nigeria.

Contributions: The authors contributed equally.

Conflict of interest: The authors declare no potential conflict of interest.

Ethics approval and consent to participate: Not required.

Received for publication: 27 July 2020.

Accepted for publication: 29 July 2020 .

This work is licensed under a Creative Commons Attribution NonCommercial 4.0 License (CC BY-NC 4.0).

CC Copyright: the Author(s),2020

Licensee PAGEPress, Italy

Annals of African Medical Research 2020; 3:108

doi:10.4081/aamr.2020.108

\section{Introduction}

The coronavirus disease 2019 (Covid-19) pandemic has reignited debate on healthcare quality at Nigeria's tertiary hospitals, which had faced much criticism in 2019 following public complaints of substandard service and maltreatment of patients. ${ }^{1-6}$

Public complaints provide valuable insight into the problems of healthcare organisations. ${ }^{7}$ For instance, Britons submitted an average of 480 written complaints to the National Health Service of the United Kingdom during 2013 and 2014, most of which bordered on investigations and treatment, problems with communication, and a perceived lack of respect for patients. ${ }^{8}$

Complaints in Nigeria dwell mainly on poor infrastructure, long patient waiting times and high costs of treatment. ${ }^{2,4}$ Some hospitals reportedly stopped neuroimaging and dialysis services due to faulty equipment, while others operated in darkness for lack of generator fuel. ${ }^{2}$ There were even reports of patients having to clean toilets and paying to repair faulty ceiling fans at a cashstrapped tertiary hospital in Northwest Nigeria. ${ }^{2}$

Peer-reviewed studies from Nigeria have equally documented equipment and infrastructure deficits. In a survey of asthma care at 68 tertiary hospitals, Desalu et al. reported only $29.4 \%$ of hospitals had spirometers for lung function tests while blood gas analyzers, pulse oximeters and nebulizers were available at only $17.6 \%$, $38.2 \%$ and $41.2 \%$ of hospitals respectively. ${ }^{9}$ Another study identified postpartum hemorrhage as a major cause of maternal deaths at 42 tertiary hospitals but found $12.7 \%$ of those hospitals lacked blood and blood products when needed for obstetric emergencies. ${ }^{10}$

Thus, from all evidence, tertiary healthcare in Nigeria falls short of international standards. In this review, we trace the history of hospitals, discuss global best practices versus the situation in Nigeria and suggest ways to improve tertiary hospital standards in Nigeria.

\section{A history of hospitals}

The foundations of western orthodox medicine were laid by Greek philosophers, notably Hippocrates of Kos (460-370 BC) who taught that diseases were natural phenomena and not divine punishments from the gods; and Galen of Pergamon (129-216 AD) who dissected cadavers and performed animal experiments for a better understanding of human anatomy. ${ }^{11}$

Still, most Greeks and Romans believed that diseases were religious phenomena, for which they visited temples (Asclepeiae in Greece and Nosocomia in Rome), where priests offered prayers and made animal sacrifices to the healing gods. ${ }^{12}$ 


\section{The Xenons of Byzantium}

Modern hospitals owe their origins to the Xenons of Byzantium, first built in the $4^{\text {th }}$ century AD to cater for the sick, the poor, and the wayfarer. ${ }^{13}$ The first major xenon was reportedly built in $370 \mathrm{AD}$ by St Basil, the Governor and Bishop of Cappadocia. By 860 AD the Byzantine Empire had over 160 Xenons, 23 of which had medical staff. ${ }^{13}$

A famous Xenon was the 'Hospital of the Pantocrator' built by Emperor John Commenos II (1087-1143 AD), which had: "Five wards for in-patients, including a surgical ward and a women's ward. It offered between 50 and 60 beds and also maintained an out-patient clinic. Unlike other hospitals, there were provisions for heating, lighting and bed linen, as well as bathing facilities and latrines. Patients were fed a carefully planned vegetarian diet and received an allowance which enabled them to purchase additional food or drink. Medical care was supplied by a large and specialized staff of physicians, medical assistants and orderlies". ${ }^{13}$

\section{Hospitals of the Islamic Caliphate}

From circa $634 \mathrm{AD}$, parts of the Byzantine Empire fell under Islamic rule with the Muslim conquests of Syria and Egypt, which exposed Arab physicians to the ideas of Aristotle, Plato, Hippocrates and Galen. ${ }^{11}$

A hospital had existed in the Persian city of Jundishapur, built in $529 \mathrm{AD}$ by Emperor Khusraw I, who had granted refuge to Greek Nestorian Christians fleeing persecution from the Byzantine ruler Emperor Justinian. ${ }^{14}$ The Nestorians helped to establish the Jundishapur Medical Center, which housed a hospital, medical school, pharmacology laboratory and library. Many physicians of the early Islamic era trained there, including the Arab physician Harith bin Kalada. ${ }^{15}$ Muslim scholars took medical texts from the library to the 'House of Wisdom' in Baghdad and had them translated into Arabic and taught at medical schools.

The Umayyad Caliph Al-Walid I (ruled 705-715 AD) is credited with building the first major hospital, which opened in Damascus in $707 \mathrm{AD}$ and employed salaried physicians. Caliph Harun al-Rashid (ruled 786-809 AD) later built another hospital in Baghdad, headed by the physician Jibrail Ibn Bukhtyishu, son of Jirjis, the noted Nestorian Chief of Jundishapur Hospital. ${ }^{11}$

By the late $9^{\text {th }}$ century, Baghdad, Cairo and Damascus all housed hospitals where patients received treatments without regard to color, religion, social status or gender. ${ }^{16,17}$ Men and women had separate wards and were attended by nurses of the same sex, and those who recovered but were too weak for discharge were housed in convalescent wards to regain strength. ${ }^{14}$ There were separate wards for medicine, surgery, fever, wounds, mania and eye disease. Each hospital had a pharmacy, library, lecture hall, mosque and occasionally a chapel for Christian patients. Musicians were employed to comfort and cheer patients with music therapy. ${ }^{14}$

That era also witnessed the birth of medical records. Medical students were tasked with keeping the records of all patients and their treatments, which were then compiled by senior clinicians and formatted in a way later known as 'treatment based on repeated experience'. ${ }^{14}$

The licensure of physicians also began in that period. When Caliph Al-Muqtadir learnt of a patient who died from medical error in 931AD, he ordered Sinan Ibn Thabit to examine all physicians and prove they could safely practice medicine. ${ }^{18}$

Among 860 doctors examined, 160 failed and were denied practicing licenses. From that time, all medical trainees had to pass oral and practical exams before they were administered the Hippocratic Oath by the Inspector General or Muhtasib who was the ombudsman enforcing laws on health, public safety and business transactions.

Another area of progress was medical ethics. In his book Adab al-Tabib (Practical Ethics of the Physician), the $9^{\text {th }}$ century physician Ishaq Ibn Ali al-Ruhawi tasked rulers with guarding society from charlatans and proposed stiff punishments - including execution - for medical malpractice. ${ }^{19}$ Other books on ethics in that period include Al-Qanun fi al-Tibb (The Canon of Medicine) by Hussain Abdullah Ibn Sina, and Ahlaq al-Tabib (Medical Ethics) by Muhammad Zakaria Al-Razi. ${ }^{19,20}$

\section{Monasteries and modern hospitals}

According to some sources, it was the capture of Jerusalem by the crusaders in $1099 \mathrm{AD}$ which exposed Europeans to Muslim medical practice. ${ }^{20}$ The Knight Templars returned to Europe and established hospitals similar to those they had seen in Palestine, and by 1204 AD Pope Innocent III had founded the famous Hospital Santo Spirito in Rome. ${ }^{20}$

St Bartholomew's Hospital opened in London in 1123 AD as part of a monastery of the Priory Church of St. Bartholomew-TheGreat before the City of London took ownership in $1546 .{ }^{21,22}$ Another monastery opened St. Thomas Hospital, and by the early $18^{\text {th }}$ century, wealthy Britons were founding hospital charities such as The Guy's Hospital built in 1721 by Thomas Guy, London's St Mary's Hospital and the 'Hospital for the Paralyzed and Epileptic'. ${ }^{23,24}$ By the mid-19 ${ }^{\text {th }}$ century, universities and colleges, such as King's College and University College London had also built hospitals to train medical students.

Pioneers at St Bartholomew's include James Paget, William Harvey and Percival Pott who founded the fields of pathology, cardiovascular medicine and spinal surgery, while at the Hospital for the Paralyzed and Epileptic and the King's College Hospital, Bentley Todd and Hughlings Jackson researched diseases of the nervous system that still bear their names. ${ }^{25}$ Meanwhile, on the European mainland - notably France - the likes of Philippe Pinel and Jean Martin Charcot pioneered modern psychiatry and neurology at the Paris Pitie-Saltpetriere Hospital, founded in 1656.

Still, it was not until the late $19^{\text {th }}$ century that European physicians gained a holistic view of disease and its varied manifestations. This lacuna is evident from extant texts of that period, such as the 1848 edition of Buchan's Domestic Medicine. ${ }^{13}$

The book featured smallpox and measles but not their causes. Causes of fever included 'injury', 'violent emotion', 'bad air', 'irregular bowels' and 'extremes of hot and cold weather'.13 Disease treatments involved the use of laxatives and emetics to cleanse the blood of impurities, bleeding the patient and sending them to the coast to have a breath of clean air.

Little was to change even after the French chemist Louis Pasteur proposed the germ theory of disease, later corroborated by Dr. Joseph Lister in his seminal paper on the antiseptic properties of carbolic acid. A skeptical medical community discarded those views and hospital mortality rates remained high even by the late $19^{\text {th }}$ century. The same scenario existed in North America, where up till the $20^{\text {th }}$ century most hospitals "were little more than boarding houses... Patients were not examined when they were admitted, and because histories and diagnosis were seldom recorded, medical records were useless. "26 


\section{Birth of hospital standards}

To address the problems of poor hospital standards in North America, the Third Clinical Congress of Surgeons of North America at its meeting in 1912 adopted a resolution stating: "Some system of standardization of hospital equipment and hospital work should be developed, to the end that those institutions having the highest ideals may have proper recognition before the profession, and that those of inferior equipment and standards should be stimulated to raise the quality of their work. In this way, patients will receive the best type of treatment, and the public will have some means of recognizing those institutions devoted to the highest ideals of medicine".

That resolution helped in founding the American College of Surgeons (ACS) and its Hospital Standardization Program which commenced in $1917 .{ }^{26}$ In 1951, the program merged with similar programs operating in the US and Canada to form the Joint Commission on Accreditation of Hospitals which was renamed as The Joint Commission in 2007.

Hospital accreditation agencies now operating across the world include The Joint Commission, QHA Trent (UK), Accreditation Canada, DNVGL Healthcare (Norway) and the National Accreditation Board for Hospitals and Healthcare Providers (India), among others. ${ }^{27-30}$

\section{Hospital standards in Nigeria}

Nigeria lacks a hospital accreditation service, except for the National Primary Healthcare Development Agency (NPHCDA) which provides technical support to primary health centers (PHC) and sets standards for PHC services. ${ }^{31}$

Some accreditations of sorts guide hospital services in Nigeria, but criteria are not uniform. For instance, hospitals offering tertiary healthcare under the National Health Insurance Scheme (NHIS) need NHIS accreditation while those training medical doctors need accreditation by the National Universities Commission (NUC), Medical and Dental Council of Nigeria (MDCN) and two postgraduate medical colleges. ${ }^{32-36}$ Unfortunately, different accreditation standards have allowed hospitals meeting one set of regulatory requirement but failing the others, to still function as tertiary hospitals.

Other policies aimed at improving hospital standards include the Service Compact with All Nigerians (SERVICOM) launched in 2004 and the Patients' Bill of Rights of the Consumer Protection Council launched in 2018. ${ }^{37,38}$ The impact of these policies is not yet ascertained but reports suggest that Nigerian hospitals have not attained desirable standards. ${ }^{1,2,9}$

The Nigerian government also enacted the National Health Act 2014 which established a National Tertiary Health Institutions Standards Committee (NTHISC) charged with maintaining tertiary hospital standards through issuance of Certificate of Standards and penalties on substandard hospitals that may include closure and criminal prosecution of indicted officials. ${ }^{39}$ The NTHISC is also charged with advising government on the "financial needs of tertiary health services, training and research".

Presently, the NTHISC internet portal has "Improvement Checklists" for tertiary hospitals with numerical scores awarded for each healthcare service category. ${ }^{40}$ Unfortunately, NTHHISC is yet to function six years after passage of the National Health Act.

\section{Challenges facing Nigeria's tertiary hospitals}

Nigeria's health workforce is grossly inadequate due to poor funding, bureaucratic restrictions and the brain-drain phenomenon. The World Health Organization (WHO) has placed Nigeria among nations with a low density of skilled workforce. While Nigeria has a skilled workforce of 22.8/10,000 population, Egypt, a fellow African country, boasts of 59.4 skilled workforce per 10,000 population. $^{41}$

Physician shortages have seen Nigerian doctors attending to 100 patients in a day, while nurses equally lament on overwork and poor renumeration. ${ }^{42,43}$ Other personnel problems include poor work ethics of healthcare workers, inter-professional rivalries and incessant industrial disputes. ${ }^{44,45}$

Virtually all communities in Nigeria lack ambulance services and pre-hospital care. Hospital emergency units are ill-equipped to resuscitate critically ill patients due to routine shortages of emergency drugs and vital consumables while patients face long waiting times at specialist clinics, with many hospitals declining admissions for lack of bed space. ${ }^{46}$

Inadequate facilities limit the range of diagnostic tests performed at tertiary hospitals. For instance, interventional radiology, autoantibody serology and hormonal assays routinely performed at small hospitals overseas are rarely available at Nigerian hospitals, thus limiting diagnostic capacity. ${ }^{47}$

Anesthesia and surgical care are equally challenged in Nigeria. Obstetric services are hampered by ill-equipped operating theaters and scarcity of fetal monitors, ultrasound scanners, and blood and blood products while long waiting times deprive surgical patients of life-saving procedures. ${ }^{10,48,49}$ Minimal-access surgery is widely under-utilized for the same lack of equipment and trained personnel. ${ }^{50}$

Few tertiary hospitals perform cardiothoracic and neurosurgical procedures, thus forcing patients to attend private hospitals or travel abroad at huge expense. Operating theatres often lack monitors, diathermy and suction equipment, just as blunt surgical instruments are seldom replaced when due.

Physician anesthetists are few, leaving nurse anesthetists to render anesthesia. ${ }^{51}$ Infrastructure deficit has seen patients given oxygen or oxygen with nitrous oxide when medical air is the better option. Few hospitals can monitor intraoperative ECG, end tidal $\mathrm{CO}_{2}$, neuromuscular function and invasive cardiovascular indices, just as they lack adequate stock of opioid analgesics for post-operative care.

Intensive care units (ICUs) lack adequate beds and ventilators. By March 2020 when the Covid-19 pandemic had reached Nigeria, public hospitals had a total of only 350 ICU beds and fewer ventilators for a population of 200 million people, according to reports of a meeting between hospital administrators and the head of the Nigerian Center for Disease Control (NCDC). ${ }^{52}$

Indeed, every hospital service in Nigeria suffers inadequate manpower and equipment, further compounded by extraneous factors such as poor electricity supply from the national grid. ${ }^{53,54}$

\section{Prospects and opportunities}

The National Health Act 2014 may well address many of these challenges given the statutory powers of the National Tertiary Health Institution Standards Committee. What remains unclear is when the committee will begin to function, and which set of standards will be adopted.

The US Joint Commission operates uniform international standards for accredited hospitals, which are summarized in a manual available on its internet website 
(jointcommissioninternational.org). ${ }^{55}$ These standards emphasize best hospital practices with specific guidelines on patient safety, medication management, anesthesia, surgical procedures, use of health information technology systems, and use of laboratory services and diagnostic imaging. The standards also cover hospital clinical ethics, facility management, disaster preparedness and fire safety.

For US hospitals, Joint Commission standards also include treatment outcomes and other performance measures, such as the National Hospital Inpatient Quality Measure on hospital-acquired sepsis and venous thromboembolism, and Disease-Specific Care Certification such as the Comprehensive Stroke Center certification, Orthopedic Rehabilitation Center certification, etc.

\section{Conclusions}

Insufficient manpower and equipment caused by poor government funding are the major obstacles to tertiary hospital services in Nigeria. Remedial attempts failed in the past due to failure of government to set uniform standards for tertiary hospitals. The National Tertiary Health Institutions Standards Committee could address the problem, but it has not functioned six years after creation. Meanwhile, another law to provide additional funding of tertiary hospitals with $1 \%$ federation account revenues has remained in legislative limbo. If Nigerian hospitals are to meet global standards in the era of COVID-19, the time to act is now.

\section{References}

1. ABU Teaching Hospital: Where patients contribute money to fix broken facilities. Daily Trust newspapers, 21st April, 2019. Accessed 4th June, 2019 at https://www.dailytrust. com.ng/abu-teaching-hospital-where- patients-contributemoney-to-fix-broken-facilities.html.

2. Vital equipment shortage hits public teaching hospitals. Punch newspapers, 23rd April, 2019. Accessed 4th June, 2019 at https://punchng.com/vital-equipment-shortage-hits-publicteaching -hospitals/.

3. Health sector crisis; patients sleep on bare floors, battle mosquitoes in teaching hospitals. Punch newspapers, 24th April, 2019. Accessed 4th June, 2019 at https://punchng.com/healthsector-crisis-patients-sleep-on-bare-floors-battle-mosquitoesin-teaching-hospitals/

4. Patients decry high costs, poor services at teaching hospitals. Daily Trust newspapers, 6th May, 2019. Accessed 4th June, 2019 at https:/www.dailytrust.com.ng/patients-decry-highcost-poor-services-at-teaching-hospitals.html.

5. After Daily trust investigations, senate probes states of teaching hospitals. Daily trust newspapers, 8th May, 2019. Accessed 4th June, 2019 at https://www.dailytrust.com.ng/after-dailytrust-investigation-senate-probes-state-of-teachinghospitals.html.

6. FG steps up quality, standards in teaching hospitals. Vanguard newspapers, 22nd May, 2019. Accessed 4th June, 2019 at https://www.vanguardngr.com/2019/05/fg-steps-up-qualitystandards-in-tertiary-hospitals/.

7. Donaldson L. An organization with a memory: Learning from adverse events in the NHS. Department of Health, London; 2000.

8. The HNS receives 480 written complaints per day. NHS Digital, 28th March, 2019. Accessed 5th June, 2019 at https://webarchive.nationalarchives.gov.uk/2018032809/http:/ /content. digital. nhs.uk/article/5005/The-NHS-receives-480written-complaints-per-day.

9. Desalu OO, Onyedum CC, Iseh KR, et al. Asthma in Nigeria: Are the facilities and resources available to support internationally endorsed standards of care? Health Policy 2011;99: 250-4.

10. Oladapo OT, Adetoro OO, Ekele BA, et al. When getting there is not enough: A nationwide cross-sectional study of 998 maternal deaths and 1451 near-misses in public tertiary hospitals in a low-income country. BJOG 2016;123:928-38.

11. Miller TS. The birth of the hospital in the Byzantine Empire. John Hopkins Press, Baltimore, 1997.

12. Nagamia HF. Islamic medicine history and current practice. J Int Soc History Islamic Med 2003;2:19-30.

13. Brought to Life: Exploring the History of Medicine. Science Museum London website. Accessed 8th July 2013 at http://www.sciencemuseum.org.uk/broughttolife/people/ byzantinehospitals.aspx.

14. Miller AC. Jundi-Shapur, bimaristans, and the rise of academic medical centers. J Royal Soc Med 2006; 99: 615-617.

15. Brewer H. Historical perspectives on health. Early Arabic medicine. J Soc Health 2004;124:184-7.

16. Stone C, Lunde P. Early Islamic hospitals; in the hospital bazaar. Health Social Services J 1981;91:1548-51.

17. Galton DJ. Destruction of a hospital. J Royal Soc Med 1997;90:406-8.

18. Syed IB. Islamic Medicine: 1000 years ahead of its times. J Int Soc History Islamic Med 2002;2:2-9.

19. Shanks NJ, Al-Kalai D. Arabian medicine in the Middle Ages. J Royal Soc Med 1984;77:60-6.

20. Gohlman WE. The life of Ibn Sina. A critical edition and annotated translation (Studies in Islamic Philosophy and Science). Suny Press, New York, 1974.

21. Ansari ASB. Abubakar Muhammed Ibn Yahya: Universal scholar and scientist. Islamic Studies 1976;15:155-66.

22. Our History. St Bartholomew Hospital London website. Accessed 1st June, 2019 at http:// www.bartshealth.nhs.uk/ourhospitals/st-bartholomew/.

23. The Development of the London Hospital System, $1823-$ 2013, The Blurb website. Accessed 7th June, 2019 at http://www.blurb. com/b/4461771-the-development-of-thelondon-hospital-system-1823

24. The Founding and Early Years of the National Hospital, Queen Square. Queen Square Archives. Accessed 20th June, 2019 at http:// www.queensquare.org.uk/archives /collection/.

25. Critchley M. The beginnings of the National Hospital (18591860). BMJ 1960; 5189: 1829-1837.

26. Roberts JS, Coale JG, Redman RR. A history of the Joint Commission on Accreditation of hospitals. JAMA 1987; 258: 936-940.

27. QHA Trent website. Accessed 1st June, 2019 at https://www.imtj.com/organisation-details/qha -trent-3103/.

28. Accreditation Canada website. Accessed 1st June 2019 at https://accreditation.ca/intl-en/.

29. DNVGL website. Accessed 1st June, 2019 at https://www.dnvgl.com/assurance/healthcare/ index.html.

30. National Accreditation Board for Hospitals and Healthcare Providers (NABH) website. Accessed 21st June, 2019 at https://nabh.co/.

31. Minimum Standards for Primary Healthcare in Nigeria. National Primary Healthcare Development Agency website. Accessed 17th June, 2019 at http://nphcda.gov.ng/publica- 
tions/.

32. NHIS Operational Guidelines. National Health Insurance Scheme website. Accessed 17th June, 2019 at https://www.dhmlnigeria.com/downloads/NHIS_OPERATIONAL_GUIDELINES (Revised).pdf.

33. National Universities Commission website. Accessed 17th June, 2019 at http://nuc.edu.ng/.

34. MDCN Mandate, Mission and Vision. Medical and Dental Council of Nigeria website. Accessed 17th June, 2019 at https://www.mden.gov.ng/page/about-us/mden-mandate-mission-vission.

35. Establishment and functions. National Postgraduate Medical College of Nigeria website. Accessed 30th April, 2020 at https://npmcn.edu.ng/about-us/establishment-and-functions/.

36. College History. West African College of Surgeons website. Accessed 30th April, 2020 at https://www.wacscoac.org/index.php/about-us/college-history.

37. About Servicom. Servicom website. Accessed 18th June, 2019 at https://servicom.gov.ng/our-clinic/about/.

38. Patients' Bill of Rights, Consumer Protection Council website. Accessed 19th June, 2019 at http://cpc.gov.ng/uploads/files/patients-bill-of-rights-full-version.pdf.

39. National Health Act 2014. Center for Laws of the Federation of Nigeria website. Accessed 8th June, 2019 at http://lawnigeria.com/Laws oftheFederation/National-Health-Act,2014.html.

40. Improvement Checklists for Federal Tertiary Institutions. Federal Ministry of Health website. Accessed 20th June, 2019 at https://www.health.gov.ng/doc/Preliminary_pages.pdf.

41. A Universal Truth: No Health Without A Workforce, World Health Organization website. Accessed 16th June, 2019 at https://www.who.int/workforcealliance/knowledge/resources/ GHWA-a_universal_truth_report.pdf?ua $=1$.

42. Inside Nigerian public hospitals where one doctor attends to 100 patients per day. Punch newspaper, 23rd June, 2018. Accessed 24th June, 2019 at https://punchng.com/inside-nigerian-public-hospitals-where-one-doctor-attends-to-100patients-per-day/.

43. Doctors, nurses lament poor pay, overwork in state hospitals. Punch newspaper, 21st May, 2019. Accessed 16th June, 2019 at https://punchng.com/doctors-nurses-lament-poor-pay-overwork-in-state-hospitals/.

44. Ninety percent deaths in Nigerian hospitals caused by health workers' attitude. Premium Times newspaper, 19th September,
2017. Accessed 20th June, 2019 at https://www.premiumtimesng .com/news/top-news/243653-90-deaths-nigerian-hospitals-caused-health-workers-attitude-teaching-hospitalchief.html.

45. Lomgurum MT, Godowoli AH. The nature of competition and conflicts among health professionals in Nigeria. Nig Hosp Pract, 2008; 2:42-48.

46. Bed space is our biggest challenge - LASUTH Board. Vanguard newspaper, 3rd November, 2014. Accessed 15th June, 2019 at https://www.vanguardngr.com/2014/11/bedspace-biggest-challenge-lasuth-board-3/.

47. Why misdiagnoses are rampant in Nigeria. The Nation newspaper, 19th October, 2018. Accessed 17th June, 2019 at https://thenationonlineng.net/why-misdiagnoses-are-rampantin-nigeria/.

48. Lawani LO, Eze JN, Anozie OB, et al. Obstetric analgesia for vaginal birth in contemporary obstetrics: a survey of the practice of obstetricians in Nigeria. BMC Pregnancy Childbirth, 2014; $14: 140$.

49. Hussein J, Hirose A, Owolabi O, et al. Maternal death and obstetric care audits in Nigeria: a systematic review of barriers and enabling factors in the provision of emergency care. Reprod Health 2016;13:47.

50. Nwankwo EO, Ibeh IN, Enabulele OI. Incidence and risk factors of surgical site infections in a tertiary health institution in Kano, North-western Nigeria. Int J Infect Control 2012;8:14.

51. Onyekwulu FA, Nwosu ADG, Ajuzieogu VO. Anaesthesia manpower need in Nigeria. Orient J Med 2014;26:83-7.

52. Coronavirus: Nigeria has 350 ICU beds for 200 million people. Premium Times newspaper, 30th March, 2020. Accessed 30th April, 2020 at https://www.premiumtimesng.com/news /headlines/384840-coronavirus-nigeria-has-350-icu-beds-for-200million-people.html.

53. CMDs lament inadequate funding of teaching hospitals. Punch newspapers, 22nd April, 2019. Accessed 6th June, 2019 at https://punchng.com/cmds-lament-inadequate-funding-ofteaching -hospitals/.

54. Torkula TT. Challenges in quality care delivery in tertiary health facilities in Northcentral Nigeria. Walden Dissertations and Doctoral Studies Collection. Walden University, 2020.

55. Joint Commission International Accreditation Standards for Hospitals. Accessed 7th July, 2019 at https://www.jointcommissioninternational.org/assets/3/7/JCI_Hosp_Standards_6th_ STANDARDS_ONLY_14Jan2018.pdf 